\title{
6306 SAYILI KANUN KAPSAMINDA KENTSEL DÖNÜŞÜM
}

\author{
Araş. Gör. Filiz DAŞKIRAN* \\ Araş. Gör. Duygu AK ${ }^{* * *}$
}

\begin{abstract}
ÖZET
Türkiye'de yerleşim alanlarının büyük bir bölümünün doğal afet riski altında olduğu bilinmektedir. Özellikle deprem, Türkiye’nin önemli bir gerçeğidir ve depreme yönelik tedbir alınmadan inşa edilen binalar durumu daha tehlikeli hale getirmektedir.

Türkiye'de söz konusu afet risklerine ilişkin çeşitli dönemlerde çıkarılan düzenlemeler mevcuttur; ancak bu yasalar çoğunlukla afet sonrast rehabilitasyon sürecini hedef almaktadır. Oysa yapılması gereken, önleyici politikaların benimsenmesidir. Buna yönelik 2012 yılında yürürlüğe giren 6306 sayılı “Kentsel Dönüşüm Yasası”nn amacı, afet riski altındaki alanlarda sağllklı ve güvenli yaşama çevreleri oluşturmak üzere gerekli usul ve esaslarl düzenlemektir. Kanuna yöneltilen eleştirilerin bir yönü, merkezi yönetime geniş yetkiler tanınması hakkındadır. Diğer grup eleştiriler ise mülkiyet hakkının ihlaline odaklanmaktadır.

Çalışmanın amacl, Türkiye açısından önemli bir sorun olan doğal afet riski altındaki alanların dönüştürülmesine yönelik kanuna ilişskin eleştirel bir bakış açısı oluşturmaktır. Çalışmada kentsel dönüşümün tanımı, tarihçesi, Türkiye'deki hukuki dayanakları ve 6306 sayılı Kanunun uygulanmasına ilişkin sorunlar ve eleştiriler yer almaktadır.
\end{abstract}

Anahtar Kelimeler: Kentsel dönüşüm, 6306 sayılı Kanun, Doğal afetler, Afet riski, Türkiye.

\section{URBAN TRANSFORMATION WITHIN THE CONTEXT OF LAW NO. 6306}

ABSTRACT

In Turkey it's known that most of the settlements are under the risk of natural disaster. Especially earthquake is an important fact of Turkey and buildings without taking precaution towards the earthquake make this situation more dangerous.

In Turkey there are many regulations subject to these risks that are enacted several terms; but most of them target rehabilitation process after the disaster. In fact what should be done is to adopt preventive approaches. Intended for this, law no.6306 that is accepted as "Urban Transformation

\footnotetext{
* Muğla Sıtkı Koçman Üniversitesi, İktisadi ve İdari Bilimler Fakültesi, İktisat Bölümü, filizcls@gmail.com.

** Muğla Sitkı Koçman Üniversitesi, İktisadi ve İdari Bilimler Fakültesi, Kamu Yönetimi Bölümü, ak87.duygu@gmail.com.
} 
Law" enures in 2012. The aim of the law is to regulate procedures and principles which are necessary on the areas under the risk of disaster in order to constitute healthy and secure living environments. One part of the criticisms that raised against the law is about giving central administration broad authority. Other group criticisms focus on violation of proprietary right.

The aim of the study is to constitute critical perspective related to the law on the conversion of areas under risk of disaster which is an important problem for Turkey. Definition and history of urban transformation, legal basis in Turkey and problems and criticisms related to the implementation of law no. 6306 take part in the study.

Key Words: Urban Transformation, Law no. 6306, Natural disasters, Risk of disaster, Turkey.

JEL Kodu: R52, R58, Z18

\section{GİRIŞ}

1999 yılındaki büyük Marmara depremi sırasında yaklaşık 17 bin kişinin depreme uygun inşa edilmeyen güvensiz binalar nedeniyle hayatını kaybettiği tespit edilmiştir. Deprem bir doğal afet olmakla birlikte depremlerde yaşanan yıkımlar, can ve mal kayıpları, binaların bu riski dikkate almadan sağlıksız bir şekilde inşa edilmiş olmasından kaynaklanmaktadır. Başka bir şekilde ifade edecek olursak, depremlerde yaşanan yıkımlar kader değildir ve riske uygun bir yapılaşma oluşturulması ile önlenebilir.

Türkiye'de deprem riskinin yüksekliğine karşın alınan tedbirler yetersizdir. Erzincan, Marmara ve Van depremleri bu gerçeği gözler önüne sermiştir. Özellikle 1999 Marmara Depremi sonrasında çok sayıda yasal düzenleme yapılarak depremin neden olduğu zararların en aza indirilmesi ve mevzuat eksikliğinin giderilmesine çalışılmıştır. Bu düzenlemeler ile afetlerle mücadele stratejisi değiştirilerek afet öncesi risk azaltma çalışmalarına ağırlık verilmiştir (Türkiye Habitat III Ulusal Raporu, 2014: 17).

27 Ağustos 1999'da 4452 sayılı Doğal Afetlere Karş1 Alınacak Önlemler ve Doğal Afetler Nedeniyle Doğan Zararların Giderilmesi İçin Yapılacak Düzenlemeler Hakkında Yetki Kanunu'nun yürürlüğe girmesiyle 27 Aralık 1999'da 587 sayılı Zorunlu Deprem Sigortasına Dair Kanun Hükmünde Kararname çıkarılmıştır. 587 sayılı Kanun Hükmünde Kararname ile belediye mücavir alan sınırları içindeki konut sahipleri için deprem sigortası yaptırmak zorunlu hale getirilmiş ve bu sigortayı sunmak üzere kamu tüzel kişiliğine sahip Doğal Afet Sigortaları Kurumu (DASK) kurulmuştur (www.deprem.gov.tr). Zorunlu deprem sigortas1 uygulamas1 2012 y1lında deprem dışındaki afetleri de sigorta kapsamına alacak şekilde genişletilmiştir (Türkiye Habitat III Ulusal Raporu, 2014: 18).

18 Mayıs 2012 tarihinde yürürlüğe giren 6305 sayılı Afet Sigortaları Kanunu ile 587 sayılı Kanun Hükmünde Kararname yürürlükten kaldırılmıştır (md. 15). Bu kanunda zorunlu deprem 
sigortasına tabi olan meskenler; "Kat Mülkiyeti Kanunu kapsamındaki bağımsız bölümler, tapuya kayıtlı ve özel mülkiyete tabi taşınmazlar üzerinde mesken olarak inşa edilmiş binalar, bu binaların içinde yer alan ve ticarethane, büro ve benzeri amaçlarla kullanılan bağımsız bölümler ile doğal afetler nedeniyle Devlet tarafından yaptırılan veya sağlanan kredi ile yapılan meskenler” olarak belirlenmiştir (md. 10). Bu kanun ile zorunlu deprem sigortasına giren konutların oranı 2013 yılı itibariyle \%28'den \%36’ya yükselmiştir (Türkiye Habitat III Ulusal Raporu, 2014: 18).

4452 sayılı Yetki Kanunu'na dayanılarak çıkarılan diğer bir yasal düzenleme, 595 sayılı Yapı Denetimi Hakkında Kanun Hükmünde Kararname'dir. Anayasa Mahkemesi'nin bu kanun hükmünde kararnameyi iptal etmesi üzerine ilk başta 19 ilde uygulanmaya başlanan 4708 sayılı Yapı Denetimi Hakkında Kanun yürürlüğe girmiştir. 4708 sayılı Kanunun amac1; "imar planına, fen, sanat ve sağlık kurallarına, standartlara uygun kaliteli yapı yapılması için proje ve yapı denetimini sağlamak ve yapı denetimine ilişkin usul ve esasları düzenlemektir" (md. 1).

Ancak Türkiye Deprem Haritası'na göre Türkiye'de birinci derece deprem bölgesi içinde yer alan 50 il varken, yalnızca milli gelirden \%67 gibi büyük bir pay alan 19 ilin kanun kapsamına dahil edilmesi, yapı denetiminin bir piyasa faaliyeti olarak görülerek ticarileştirildiği şeklinde eleştirilere neden olmuştur (TMMOB, 2011: 19).

Kuşkusuz 1999 Marmara Depremi sonrasına yürürlüğe konan yasal düzenlemeler yalnızca bunlarla sınırlı değildir. Toplam 38 kanun ve kanun hükmünde kararname, 28 kararname, 6 yönetmelik, 17 tebliğ ve 9 genelde yürürlüğe girmiştir ${ }^{1}$. Ayrıca 2004 yılında gerçekleştirilen Deprem Şurası'nda Türkiye'nin deprem politikasına yönelik önemli kararlar alınmış, 2006'da Deprem Yönetmeliği güncellenmiş, 2009 yılında yeni bir kurumsal yapılanmaya gidilerek afet öncesi ve sonrasına yönelik tüm koordinasyon işleri Afet ve Acil Durum Yönetimi Başkanlığı'nda (AFAD) toplanmış, 2011 yılında Ulusal Deprem Stratejisi ve Eylem Planı (2023) hazırlanmıştır (Türkiye Habitat III Ulusal Raporu, 2014: 18).

$\mathrm{Bu}$ tedbirler ve düzenlemelerin yanı sira 31 Mayıs 2012 tarihinde 6306 sayılı Afet Riski Altındaki Alanların Dönüştürülmesi Hakkında Kanun yürürlüğe girmiş ve kentsel dönüşümün çerçevesi belirlenmiştir. Bu doğrultuda çalışmanın amacı, Türkiye açısından önemli bir sorun olan doğal afet riski altındaki alanların dönüştürülmesine yönelik kanuna ilişkin eleştirel bir bakış açısı oluşturmaktır. Çalışmada kentsel dönüşümün tanımı, tarihçesi, Türkiye'deki hukuki dayanakları ve 6306 sayılı Kanunun uygulanmasına ilişkin sorunlar ve eleştiriler yer almaktadır.

\footnotetext{
${ }^{1}$ Söz konusu yasal düzenlemeler hakkında daha fazla bilgi için bkz. www.deprem.gov.tr/sarbis/DDK/DDKIV/DDKIV .../G-Bölümü.doc (12. 05. 2015).
} 


\section{KENTSEL DÖNÜŞÜMÜN TANIMI}

Günümüz Türkiye'sinde en çok konuşulup, üzerinde tartış1lan konulardan birisi olan kentsel dönüşüm ekonomik, sosyal ve politik birçok kesim tarafından araştırılmaktadır. Bu kadar gündemde olan kentsel dönüşüm kavramı özünde aynı kapıya çıkan ama farklı yollarla anlatılmaya çalışılan birçok tanıma sahiptir. Bunun nedeni, kentsel dönüşüm sürecinin kapsam ve amaç bakımından ülkelerin ekonomik, siyasi ve sosyal koşullarına göre farklılık göstermesidir (Aydınlı ve Kaya, 2013: 451).

Kentler sürekli bir devinim içerisinde bulunmaktadır. Arazilerin kullanım şekli değişmekte, arsalar yenilenmektedir. Kentler zamanla genişlemekte, nadiren olsa da bazen küçülebilmektedir. Arazinin kullanım şeklini değiştirmek için ekonomik, çevresel, sosyal ihtiyaçlar veya bunların bir araya getirilmesi gibi birçok neden meydana gelmektedir (Jones and Evans, 2008: 1-2). Bu bağlamda kentlerin değişime uğramasında bu ekonomik, çevresel ve sosyal faktörlerin çözümlenmeye çalışılması dönüşümü ortaya koymaktadır.

Kentsel dönüşüm, kentin imar planına uymayan ruhsatsız binaların yıkılıp, planlara uygun olarak toplu yerleşim alanlarının oluşturulmasıdır (www.tdk.gov.tr, 2006). Başta İngiltere ve Amerika Birleşik Devletleri’nde olmak üzere kent planlamasının gündemine giren ve giderek önemli bir yer kazanan kentsel dönüşüm; yerel ekonomiye ait dinamikleri harekete geçirerek fiziksel ve sosyal yönlerden çöküntü sürecine girmiş kentsel alanları yeniden yaşanabilir yerler haline getirmeyi ve kente yeniden canlılık kazandırmayı hedefleyen bir planlama ve koruma yaklaşımıdır (Görün ve Kara, 2010: 144).

Kent nüfuslarının giderek arttığı günümüz koşullarında hayatımıza yeni bir kavram olarak giren kentsel dönüşüm genel olarak, "bir kentsel alanın amaçlı olarak belirli bir zaman dilimi içinde, yeniden geliştirilmesi yönünde iş olanakları yaratılarak, altyapı koşulları iyileştirilerek ve çevresel yenileme sağlanarak yeniden yapılandırılması” ş̧eklinde tanımlanabilir (Ergun ve Gül, 2010: 364-365).

Kentsel dönüşüm, "fiziksel/tasarım, sosyal, ekonomik ve yasal/yönetsel boyut” olmak üzere birbirini tamamlayan dört boyutu içinde barındıran bir kavramdır. Ekonomik, toplumsal ve mekânsal pek çok planlama eylemini, yasaları, politikaları, ekonomik karar ve tercihleri içeren çok çeşitli aktörlerin yer alabildiği bir eylemler bütünüdür (Kocaer Şenyol ve Bal, 2013: 445).

Kentsel dönüşüm kent parçalarının kullanım biçimine dışarıdan bir müdahale sonucunda her ne kadar toplumsal, ekonomik, kültürel ve hatta siyasal amaçlarla gerçekleşse de (Keleş, 2008: 447-448) kentsel dönüşüm aslında kendiliğinden bir süreç olmaktadır. Kentler geçmişe bakıldığında 50-60 yılda bir kabuk değiştirmektedir. 50 y1l önceki İstanbul ile şu anki İstanbul arasında büyük farklılıklar 
bulunmaktadır. $\mathrm{Bu}$ bakımdan kentlerin sosyal, ekonomik ve fiziki olarak zamanla kendiliğinden dönüşüm geçirdiği söylenebilir.

Kentsel dönüşüm, uygulamanın niteliğine göre farklı biçimler alabilmektedir. Bu uygulama biçimleri, kentsel yenileme (urban renewal), sağlıklaştırma/iyileştirme/islah (rehabilitation/ improvement), koruma (preservation-conservation) ve yeniden canlandırma (regeneration) olarak adlandırılmakta ve her birinin uygulama alanı ve gerekçeleri farklı olmaktadır (Türkün, 2012: 281).

Kentsel yenileme projelerinde, kent içindeki kaçak yapılaşma alanları ile ekonomik ömrünü doldurmuş bulunan alanların gerekli tüm kentsel ve sosyal fonksiyonları yenilenerek fiziki ve coğrafi özelliklerinden kaynaklanan olası tüm doğal afet riskleri de ortadan kaldırılacak şekilde yeniden yapılması hedeflenmektedir (Boyraz ve Hoş, 2014: 49). Türkiye'deki dönüşüm biçimlerine bakıldığında genellikle yenilemenin ön plana çıktığı ve soylulaşmanın yolunu açan uygulamaların desteklendiği görülmektedir (Türkün, 2012: 281). Soylulaştırma kentsel dönüşümün uygulama biçimlerinden biri olmamakla birlikte, genel olarak orta ve üst-orta sınıfların, kentin içinde bulunan ve tarihsel süreçte çeşitli ekonomik, siyasal ve toplumsal koşullar sonucu çöküntü haline gelmiş alanlardaki eskimiş/bakımsızlaşmış tarihi konutların mevcut sahibi/kiracısı olan yoksul kesimle, gerek bireysel gerekse örgütlü bir restorasyon sonucu, bu konutlara yerleşerek yer değiştirmesi süreci olarak tanımlanabilir (Sönmez ve Geniş, 2013: 128).

Sağlıklaştırma (Eski Haline Getirme), alt yapısı yetersiz bir çevrenin sınırlı yatırımlarla yeterli hale getirilmesidir. Bu tür dönüşüm müdahalesi genelde gecekondu ve ruhsatsız konut alanlarında uygulanmaktadır. Islah imar uygulaması, yapılaşması yasal olmayan bir alanın yasal hale getirilmesi ve o alanda yapılaşma hakkı verilerek yaşayanlara güvence verilmesidir. (Ataöv ve Osmay, 2007: 68).

Koruma, toplumun geçmişteki sosyal ve ekonomik koşullarını, kültürel değerlerini yansıtan fiziksel yapısının, yaşanan değişim ve gelişimler nedeniyle yok olmasının engellenmesi, kentsel dokunun çağdaş yaşamla bütünleştirilmesi, kültürel varlıkların topluma faydalı, ekonomik ve işlevsel koşullarla sağlıklaştırılması şeklinde tanımlanmaktadır (Polat ve Dostoğlu, 2007: 63).

Yeniden canlandırma, özellikle eski yerleşim yerlerinde eski canlılı̆̆ını kaybeden fiziksel ve ekonomik olarak çöküntü yaşayan alanların özellikle tarihi kent merkezlerinin alınacak sosyal ve ekonomik önlemlerle yeniden canlandırılmasıdır (Saraç, 2014: 21).

Tüm bu açıklamalardan yola çıkarak kentsel dönüşümü; kentlerin ekonomik, toplumsal ve mekânsal olarak tekrar ele alınarak, istenmeyen kent dokularının çağdaş şehircilik ilkeleri ve planlama esasları doğrultusunda dönüştürülmesi süreci olarak tanımlayabiliriz (Aydınlı ve Kaya, 2013: 451). 


\section{KENTSEL DÖNÜŞÜMÜN TARİHÇESİ}

Kentsel dönüşüm olgusu ilk olarak 19. yüzyılda Avrupa'da yaşanan kentsel büyüme hareketleri sonucunda bazı bölgelerin yıkılıp yeniden yapılması şeklinde ortaya çıkmıştır. Bu bağlamda 18501860 yılları arasında Hausmann'ın Paris uygulamaları sonucunda kentte yeni bulvarlar ve geniş caddeler açılmış ve bu caddeler üzerinde apartmanlar inşa edilmiştir (Sönmez ve Sönmez, 2012: 197).

Endüstri Devrimi sonrasında, Avrupa'nın büyük kentlerinde işçi sınıfının içinde bulunduğu insanlık dışı koşullar, birçok plancıyı etkilemiş ve ilk kentsel dönüşüm fikrinin ortaya çıkmasını hızlandırmıştır. Zaman içinde kentsel dönüşüm sürecinin politik ve ekonomik yapısı, ulusal gelişimden, küresel bütünleşme hedefine yönelerek, kentsel planlama sürecini de değiştirmiştir (Şişman ve Kibaroğlu, 2009: 3).

19. yüzyıl sonunda Türkiye'de Batı ülkeleri ile ticaretin yoğunlaşması özellikle liman kentlerinde yapısal değişikliklere neden olmuş ve liman kentlerine eklenen yeni işlevler sonucunda Batı kentlerindeki uygulamalara benzer biçimde bulvarlar genişletilmiş ve konut üretiminde tek tipleşmeye gidilmeye başlanmıştır (Sey, 1998: 273).

İkinci Dünya Savaşı'nın bitmesine doğru yakılıp yıkılmış kentlerin yenilenmesi, zarar görmüş kültür miraslarının onarılması için harekete geçilmiştir. Avrupa ve Amerika'da 1950'li yıllarda savaş sonrası kentlerde yaşanan hasarlara yönelik çözüm arayışı olarak kentsel dönüşüm uygulamalarının önem kazandığını görmekteyiz. Savaş sonrası dönemde, "Modernist Hareket" kentlerin yeniden inşasını gündeme getirerek kentsel gelişim stratejisi uygulanmaya başlanmıştır. Bu dönemde merkezi yönetimin öncülüğünde yeniden yapılanma politikaları ortaya atılmıştır (Akkar, 2006: 31).

İlk kentsel dönüşüm uygulamalarının olduğu belirtilen 1950'li yıllarda, tüm kentsel alan parçalarının yıkılıp yerine yeni bir kent inşa edilmesi ve yeni caddeler oluşturularak trafiğin düzenlenmesi amaçlanırken, 1960'larda bu düşünce terk edilerek tarihi yapıların korunması hedeflenmiştir (Ayhan, 2013: 85).

1960'lar ve 1970’lerin başında kentsel yenileme yöntemine öncelik verildiği görülmektedir. Bu dönemde, kentsel bozulmanın fiziksel bozulma ile toplumsal bozulma arasında doğrudan bir bağlantı olduğu kabul edilmiş ve merkezi yönetim tarafından gerçekleştirilen dönüşüm projelerinin etkisi sınırlı kalmıştır. Ancak bu projelerin önemi, kentsel dönüşümün hem fiziksel mekan hem de toplumsal boyutlarının bir arada ele alınması gerekliliğinin yaygın olarak kabul edilmesini sağlama hususunda kendini göstermektedir (Akkar, 2006: 31).

1980 ve sonrası dönemlerde kentsel dönüşümün ekonomik boyutunun yanında sosyal boyutu da devreye girmiştir. 1980'li yıllarda kentsel dönüşümün amacı kentlerin tarihi dokusu, kentlerin cazibe merkezlerine odaklanılmıştır. Kentleri canlandırmak üzere yapılan proje giderlerinin sadece devlet 
tarafından karşılanması yerine özel sektör de devreye girmiştir. 1990 ve 2000'li yıllarda; 1980'lerdeki gibi yerel halkın yaşam koşullarının iyileştirilmesini de göz önünde bulundurulmasıyla kentsel dönüşüm mekânsal ve ekonomik dönüşümün yanında sosyal dönüşümünde bir aracı olarak görülmeye devam etmiştir (Özer vd., 2013: 4-5).

Türk planlama sisteminde ise kentsel dönüşüm bir strateji olarak uygulanmamış, Türkiye'nin bağlamsal ve uygulama dinamiklerine göre gerçekleşmiştir (Ataöv ve Osmay, 2007: 58). Türkiye'de 1950'lerde ülkenin sosyo-ekonomik yapısında yaşanmaya başlayan gelişmeler kentleşme hızının ve kentsel nüfusun artışına neden olurken, kentler bu yıllardan itibaren hiç görmedikleri ölçüde hızlı bir dönüşüm sürecine girmişlerdir. Bu süreçte yeni merkezler ortaya çıkmış, merkezi iş alanları yıkılarak yenilenmiş, kentlerin gelişme yönleri değişmiş, uydu kentlerle kent çevresindeki yeşil alanlar ve tarım toprakları konut alanına dönüştürülmüştür. Bu dönüşüm sürecinde kentler plansız gelişmeleri yanında hem doğal, tarihi ve kültürel çevreyi hem de afet risklerini göz ardı ederek büyümüşlerdir (Genç, 2014: 16).

1950'li yıllarda artan kentleşme ile birlikte çarpık yapılaşmalar ve gecekondular ortaya çıkmaya başlamıştır. Bu süreçte gerek merkezi yönetim ve gerekse yerel yönetimler, kentleşmede disiplini bir türlü sağlayamamışlardır. Bu yüzden, Türkiye"de kentleşme, devletin ve yerel yönetimlerin denetiminde ve imar planlarına göre değil, çoğunlukla her türlü kontrolden uzak bir şekilde ve yasa dışı kesimlerin etkinliğinde gelişmiştir. Dolayısıyla, başta İstanbul, Ankara ve İzmir olmak üzere Türkiye ede kentler yüz binlerce kaçak yapıyla dolup taşmıştır (Köktürk ve Köktürk, 2007: 5).

1980'lerden sonra hem gecekondular hem de kent merkezindeki eski konut alanları apartmanlara dönüşmüştür. Bu gelişmeler işgücünün örgütlenme biçimine göre çeşitlenmiştir. Kentte kalıcılık kazanan enformel kayıt dışı işgücü, işyerlerine yakın mesafede ruhsatsız ancak kalıcı nitelikli çok katlı gecekondu alanlarına yerleşmiştir. Kent ekonomisi ile bütünleşmiş ve çeşitlenmiş işgücü ise ruhsatlı veya ruhsatsız yapıların bulunduğu yeni gelişen orta ve düşük gelir grubunun oluşturduğu mahallelerdeki konutlara geçmiştir (Ataöv ve Osmay, 2007: 63).

Kentsel mekânda yaşanan değişim, 2000'li yıllarla birlikte boyut değiştirmiş, "imar rantı" kavramı "deprem korkusu” ile birleştirilerek yeni düzenlemelerin gerekçesi oluşturulmuştur. Kent içinde oluşan rantlara el koyma arayışında olanların mevcut kullanıcıları tasfiye etmek için başlattıkları arayış "Kentsel Dönüşüm” kavramı ile somutlaştırılmıştır (Kocaer Şenyol ve Bal, 2013: 447). Bu yıllarda özellikle gecekondu sorununa kentsel dönüşüm yaklaşımı ile çözüm aranmaya başlanmış̧ır. Marmara ve Düzce Depremlerinin ardından oluşan duyarlılıkla afetler karşısında risk azaltımı araçlarından biri olarak kentsel dönüşüm gündeme gelmiştir. Bayındırlık ve İskân Bakanlı̆̆ı'nın 2004 yılında düzenlediği Deprem Şurası'nın Mevzuat Komisyonu Raporunda “kentsel dönüşüm eylem planları” tanımlanırken; 2004-Türkiye İktisat Kongresi Afet Komisyonu Raporunda 
da sakınım planları kapsamında yerel yönetimlerin kentsel dönüşüm alanlarında boşaltma, yenileme, güçlendirme araçlarının geliştirilmesi önerilmektedir (Genç, 2014: 19). Daha sonra bu kentsel dönüşüm konusuna çalışmanın ilerleyen kısmında incelenecek olan hukuki dayanaklar oluşturulmuştur.

\section{TÜRKIYE'DEKİ AFET RİSKLERI}

Türkiye'de kırdan kente gerçekleşen yoğun ve hızlı göçler, kentlerin yalnızca barınma ihtiyacına yönelen ve niteliği gözetmeyen bir şekilde yapılaşmasına neden olmuştur. Bu kapsamda inşa edilen konutların kalitesi çoğu kez ihmal edilmiştir. Buna ilaveten Türkiye'de afet risklerinin yüksek olması ve geçmişte yaşanan depremlerin yüksek can ve mal kayıplarını somut bir şekilde ortaya koyması, sorunu daha da derinleştirmektedir (Özer, Yönten ve Yılmaz, 2013: 468).

Türkiye'deki yapı stokunun büyük bir kısmının eski mevzuata dayanarak, yani zorunlu deprem sigortası ve yap1 denetimi sistemine geçilmeden önce inşa edilmiş olması nedeniyle sağlıksız ve dayanıksız olduğu ve birçok kentte kaçak yapılaşma oranlarının yüksek olduğu görülmektedir. İstatistikî verilerle ifade edecek olursak; Çevre ve Şehircilik Bakanlığı Altyapı ve Kentsel Dönüşüm Hizmetleri Genel Müdürlüğü tarafından açıklanan bilgilere göre, Türkiye'deki 19 milyon konuttan 2000 y1lı sonrasında yapılan 5 milyon konut haricindeki 14 milyon konutun afet riski yönünden incelenmesi gerekmektedir (www.csb.gov.tr).

Bayındırlık ve İskân Bakanlığı Afet İşleri Genel Müdürlüğ̈̈’nün 1950-2008 y1llarını kapsayan “Türkiye'de Afetlerin Mekânsal ve İstatistiksel Dağılımı Afet Bilgileri Envanteri”nde yer alan bilgilere göre, ülkemizdeki 35.741 yerleşim biriminin \%43.75'i en az bir afet olayına maruz kalmıştır. Türkiye'de meydana gelen afetlerin \%76'sını deprem, \%10'unu heyelan, \%9'unu sel, \%4'ünü kaya düşmesi ve \%1'ini diğer afet türleri oluşturmaktadır. Türkiye Deprem Bölgeleri Haritası'na göre ise ülkemizin \%96'sı farklı derecede deprem riskine sahip bölgeler içindedir. Bu bölgelerde yaşayan nüfus, toplam nüfusun \%98'ine tekabül etmektedir (Türkiye Habitat III Ulusal Raporu, 2014: 17).

TMMOB Makine Mühendisleri Odası'nın yayımladığı raporda yer alan resmi verilere göre (2011: 8); 1999 Marmara Depremi'nde 17.480 kişi ölmüş, 43.953 kişi yaralanmış ve 505 kişi sakat kalmıştır. 12.724'ü yıkık veya ağır hasarlı olmak üzere toplam 376.479 konut ve işyeri hasar görmüş, 133.683 binanın çökmesi ile 600.000 kişi evsiz kalmıştır.

Yalnızca depremin merkez üssü olan Gölcük itibariyle düşünecek olursak, 5.383 kişinin ölmesi Gölcük'te o tarihte yaşayan her beş kişiden birinin öldüğü anlamına gelmektedir (TMMOB, 2011: 8). Sayıştay'ın “Bayındırlık ve İskân Bakanlığı'nın Marmara ve Düzce Depremleri Sonrası Faaliyetleri 
Hakkında Performans Denetim Raporu'nda ise bu veriler; 18.423 kişinin hayatını kaybettiği, 48.901 kişinin yaralandığı ve 376.379 konut ve işyerinin hasar gördüğü şeklindedir (www.sayistay.gov.tr).

Türk Sanayicileri ve İş Adamları Derneği (TÜSİAD), Devlet Planlama Teşkilatı (DPT) ve Dünya Bankası tarafından hazırlanan çalışmalarda, Marmara Depremi'nin ülke ekonomisine etkilerine dair sunulan sonuçlar birbirine oldukça yakındır. TÜSİAD'a göre depremin toplam maliyeti 17 milyar dolar, DPT'ye göre 15-19 milyar dolar ve Dünya Bankası'na göre 12-17 milyar dolardır (TMMOB, 2011: 12).

Başbakanlık Afet ve Acil Durum Yönetimi Başkanlığı (AFAD)'ın 2014 yılında yayımladığı “Müdahale, İyileştirme ve Sosyoekonomik Açıdan 2011 Van Depremi” Raporu'nda Van Depremi’nde hayatını kaybeden kişi sayısı 644, yaralanan kişi sayısı 1.966 olarak belirtilmiştir. Yapısal hasar analizinde ise toplam 48.689 ağır hasarl1/yıkık yapı ve 22.483 orta hasarlı yapı tespit edilmiştir. Kabaca bir oran vermek gerekirse her 100 yapıdan yaklaşık 77'sinin deprem nedeniyle hasar gördüğü ortaya çıkmıştır (AFAD, 2014: 20-22).

Yukarıda bahsedilen Türkiye'de Afetlerin Mekânsal ve İstatistiksel Dağılımı Afet Bilgileri Envanteri'nde nüfusu 1 milyondan fazla olan 11 büyük kent dahil olmak üzere ülke nüfusunun \%70'inin yer aldığı bölgelerde her an büyük bir deprem olma riskinin yüksek olduğu belirtilmiştir (www.afad.gov.tr). Örneğin; yapıların \%70'inin kaçak veya ruhsatsız olduğu İstanbul'da olası bir deprem için yapılan tahminler, 10.000 civarında binanın tamamen çökeceği, 50.000-60.000 binanın ağır hasar göreceği ve 40.000-50.000 kişinin yaşamını kaybedeceği yönündedir (TMMOB, 2011: 20). Bu tahminler aynı zamanda İstanbul'da yaşayanların fiziki ve moral varlığını ortadan kaldırmaya yönelik büyük bir tehdit niteliğindedir (Şahin, 2013: 428).

Yukarıda sunulan istatistikî veriler, Türkiye'deki binaların depreme karşı dayanıklılığı konusundaki gerçekleri gözler önüne sermektedir. Buna kıyasla yakın zamanda Japonya'da meydana gelen 8.8 şiddetinde depremde binaların depreme karşı ne kadar dayanıklı olduğu ortaya çıkmıştır. Türkiye'de binaların bu kadar sağlıksız ve zeminlerinin zayıf oluşu, zamanında deprem yönetmeliklerine uyulmadığını, binaların denetimsiz olarak yapılmasına izin verildiğini ve özellikle birinci derece deprem bölgelerinde hızlı bir şekilde kentsel dönüşüme gidilmesi gerektiğini gündeme getirmiştir. Depremleri en az can ve mal kaybı ile atlatmak için ilk olarak yaşam alanlarımızdan ve öncelikle de barınmamızı sağlayan konutlardan işe başlamak gerekmektedir.

Depreme dayanıklı olmayan sağlıksız yapı stoklarının deprem olmadan tespit edilerek güçlendirilmesi, gerekli olanların tümüyle yıkılarak yeniden inşa edilmesi, kaçak yapıların güvenli ve yaşam kalitesi yüksek alanlara dönüştürülmesi ülkemiz için aciliyet taşıyan konular arasındadır (Özden, 2006: 221). Bu süreç, kentin mevcut yapısına ve kentte yaşayan insanların geleceğine etki 
edeceğinden çok yönlü ve çok disiplinli bir bütünleşik çalışmayı gerektirmektedir (Öcal ve İnce, 2012: 94).

\section{TÜRKIYYE'DE KENTSEL DÖNÜŞÜMÜN HUKUKİ DAYANAKLARI}

Türkiye'de kentsel dönüşümü gerçekleştirmek üzere yürürlüğe konulmuş olan birçok yasal düzenleme bulunmaktadır. Çalışmada bu kapsamda ele alınacak olanlar;

- 3194 sayılı İmar Kanunu “Arsa ve Arazi Düzenlemesi” başlıklı 18. madde,

- 5104 say1lı Kuzey Ankara Girişi Kentsel Dönüşüm Projesi Kanunu,

- 5366 sayılı Yıpranan Tarihi ve Kültürel Taşınmaz Varlıkların Yenilenerek Korunması ve Yaşatılarak Kullanılması Hakkında Kanun,

• 5393 sayılı Belediye Kanunu “Kentsel Dönüşüm ve Gelişim Alanı” başlıklı 73. maddedir.

Türkiye'de kentsel dönüşüm uygulamalarında araç olarak kullanılabilecek önemli bir madde, 09 Mayıs 1985 tarihli ve 3194 sayılı İmar Kanunu'nun düzenleme ortaklık payını öngören 18. maddesidir (Yaman, 2012: 112). Bu maddeye göre:

"İmar hududu içinde bulunan binalı veya binasız arsa ve arazileri malikleri veya diğer hak sahiplerinin muvafakatı aranmaksızın, birbirleri ile yol fazlaları ile kamu kurumlarına veya belediyelere ait bulunan yerlerle birleştirmeye, bunları yeniden imar planına uygun ada veya parsellere ayırmaya, müstakil, hisseli veya kat mülkiyeti esaslarına göre hak sahiplerine dağıtmaya ve re'sen tescil işlemlerini yaptırmaya belediyeler yetkilidir. Sözü edilen yerler belediye ve mücavir alan dışında ise yukarıda belirtilen yetkiler valilikçe kullanılır.

Belediyeler veya valiliklerce düzenlemeye tabi tutulan arazi ve arsaların dă̆ıtımı sırasında bunların yüzölçümlerinden yeteri kadar saha, düzenleme dolaylstyla meydana gelen değer artışları karşıllğında "düzenleme ortaklık payı" olarak düşülebilir. Ancak, bu maddeye göre alınacak düzenleme ortakllk paylarl, düzenlemeye tabi tutulan arazi ve arsaların düzenlemeden önceki yüzölçümlerinin yüzde kırkını geçemez.

Düzenleme ortaklık payları, düzenlemeye tâbi tutulan yerlerin ihtiyacı olan Milli Eğitim Bakanlı̆̆ına bağlı ilk ve ortä̈ğretim kurumları, yol, meydan, park, otopark, çocuk bahçesi, yeşil saha, ibadet yeri ve karakol gibi umumî hizmetlerden ve bu hizmetlerle ilgili tesislerden başka maksatlarla kullanılamaz."

$\mathrm{Bu}$ madde ile getirilen Düzenleme Ortaklık Payı (DOP), kısaca idarenin kamulaştırma yapmaksızın taşınmaz mal edinme ve kamu yararına kullanma yöntemlerinden biridir. Yol, meydan, park, yeşil saha, genel otopark gibi ihtiyaçların karşılanması amacına yönelik olarak özel mülkiyette 
bulunan taşınmazlara yetkilendirilen idareler tarafindan el konulmasını ifade etmektedir. Taşınmazlarda düzenleme sonrasında meydana gelen değer artışı karşılığında idare, düzenlemeye tabi tutulmadan önceki yüzölçümünün \%40'ını geçmeyecek şekilde kişilerin onayı olmadan bedelsiz olarak el koyabilmektedir (Y1lmaz, 2010: 39, 42).

Bu araca dayanarak Türkiye'de gerçekleştirilen projelere örnek olarak Portakal Çiçeği Vadisi ve Dikmen Vadisi Kentsel Dönüşüm Projeleri verilebilir. Örneğin, Portakal Çiçeği Vadisi Kentsel Dönüşüm Projesi'nde önce kamulaştırma kararı alınmakla birlikte belediyenin kaynak sıkıntısı nedeniyle bu kararı uygulamaya geçirememesi üzerine bu yöntem benimsenmiştir. Burada klasik kamulaştırma yerine, imar haklarının toplulaştırılması ve arsa sahiplerinin geçmişte elde ettikleri imar hakkı karşılı̆̆ında projede yaratılacak değerden pay almaları, yani projede yaratılacak rantın uzlaşma yoluyla paylaşımı yöntemi kullanılmıştır (Göksu, 1993: 83).

Türkiye'de kentsel dönüşüm uygulamalarının yolunu açan önemli bir yasal düzenleme, 12 Mart 2004 tarihli ve 5104 sayılı Kuzey Ankara Girişi Kentsel Dönüşüm Projesi Kanunu'dur. Bu kanunun amacı; "kuzey Ankara girişi ve çevresini kapsayan alanlarda kentsel dönüşüm projesi çerçevesinde fiziksel durumun ve çevre görüntüsünün geliştirilmesi, güzelleştirilmesi ve daha sağlıklı bir yerleşim düzeni sağlanması ile kentsel yaşam düzeyinin yükseltilmesidir” (md.1).

5104 sayılı Kanun, Ankara'da "Protokol Yolu" olarak ifade edilen Esenboğa Havaalanına ulaşım yolunda bulunan (Öngören ve Çolak, 2013: 64) ve daha önceleri farklı belediyelerin yetki alanına dâhil olan gecekonduların Ankara Büyükşehir Belediyesi’ne yetki verilerek kente yeniden kazandırılmasını; böylece kentin o bölgesinin hem fiziksel hem de estetik açıdan iyileştirilmesini hedeflemektedir (Genç, 2014: 20). Ankara Büyükşehir Belediyesi ile Toplu Konut İdaresi (TOKI)'nin yetkilendirildiği bir kentsel dönüşüm uygulamasıdır (Yenice, 2014: 84).

5104 sayılı Kanun, iki açıdan bir ilk olma özelliği taşımakta ve bu nedenle Türkiye'deki diğer örneklerinden ayrılmaktadır. Bunlardan birincisi; yalnızca kentin belirli bir alanını kapsayan bir kentsel dönüşüm öngörüyor olmasıdır (Uzun, 2006: 51). İkincisi ise kendisini özel bir yasal altlıkla destekliyor olmasıdır (Dükkanc1, 2013: 46).

Söz konusu iki özelliğinin yanı sıra 5104 sayılı Kanun birçok açıdan eleştirilere maruz kalmıştır. Genel olarak kanunun kentin belirli bir bölümünü kapsaması nedeniyle parçacı yaklaşımların egemen olmasına yol açtığı söylenmektedir (Uzun, 2006: 51). Ayrıca kanun, amaç kısmından da anlaşılacağı üzere, yalnızca dönüşümün fiziksel yönüne odaklanmaktadır. Bu alanda yaşayan gecekondu sahiplerinin sosyo-ekonomik durumuna ilişkin herhangi bir amaç belirtilmemiştir (Aydınlı ve Turan, 2012: 67). Yani fiziksel bir yenileme söz konusu olsa bile sosyal açıdan eksikliklerin olduğu görülmektedir (Dükkanc1, 2013: 49). 
Bunun ardından 05 Temmuz 2005 tarihli ve 5366 sayılı Yıpranan Tarihi ve Kültürel Taşınmaz Varlıkların Yenilenerek Korunması ve Yaşatılarak Kullanılması Hakkında Kanun’un amac1; “... yıpranan ve özelliğini kaybetmeye yüz tutmuş; kültür ve tabiat varlıklarını koruma kurullarınca sit alanı olarak tescil ve ilan edilen bölgeler ile bu bölgelere ait koruma alanlarının, bölgenin gelişimine uygun olarak yeniden inşa ve restore edilerek, bu bölgelerde konut, ticaret, kültür, turizm ve sosyal donatı alanları oluşturulması, tabii afet risklerine karşı tedbirler alınması, tarihi ve kültürel taşınmaz varlıkların yenilenerek korunması ve yaşatılarak kullanılması" olarak ifade edilmiştir (md.1).

5366 sayılı Kanunla getirilen kentsel dönüşüm süreci, yıpranmış tarihi alanların yıkılarak daha fazla kazanç ve rant güdüsü ile fiziksel olarak yenilenmesi olarak tariflenmektedir (Dükkanc1, 2013: 83). Kanun, dönüşüm alanlarının belirlenmesini il özel idarelerinde il genel meclisinin, belediyelerde ise belediye meclisinin salt çoğunluk kararına bağlamıştır. Bununla birlikte TOKI'nin ortak veya tek başına uygulama yapabileceğine yönelik yasal zemin hazırlanmışıı (Yenice, 2014: 84). Kanundaki düzenlemelere dayalı olarak uygulanan kentsel dönüşüm projelerine Sulukule, Tarlabaşı ve Ayazma projeleri örnek olarak verilebilir. Ancak bu uygulamaların kanunun öngördüğü yenileme ve koruma amacından uzaklaştığı görülmüştür (Demirkol ve Baş, 2013: 40).

5366 sayılı Kanunda yıpranan ve özelliğini kaybetmeye yüz tutmuş bölgelerin belirleneceği ölçütler somut olarak açıklanmamakta ve buna ilişkin bilimsel kriterlere yer verilmemektedir (Uzun, 2006: 51). Ayrıca koruma amaçlı imar planlarını göz ardı etmesi, uygulama için gerekli araçları tanımlamamış olması ve Kültür ve Tabiat Varlıklarını Koruma Kanunu ile doğrudan ilişkili olmasına rağmen referans vermemiş olması da 5366 sayılı Kanunun olumsuz yönleri arasında sayılmıştır (Özden, 2006: 224-225).

Ülkemizde kentsel dönüşüm geçmişte ve günümüzde temeli 5393 sayılı Belediye Kanunu'na dayandırılarak yürütülmüştür. Belediye Kanunu'nun “ Kentsel Dönüşüm ve Gelişim Alanı” başlıklı 73. maddesinde kentsel dönüşüme yönelik düzenlemeler yer almaktadır. Bilindiği üzere 13 Temmuz 2005 tarihli ve 5393 sayılı Belediye Kanunu'nun 73. maddesi, "Belediye Kanununda Değişiklik Yapılmasına İlişkin Kanun” adını taşıyan 5998 sayılı kanunun 24 Haziran 2010 tarihinde Resmi Gazete'de yayımlanarak yürürlüğe girmesiyle değiştirilmiştir. Buna göre:

"Belediye, belediye meclisi karartyla; konut alanları, sanayi alanları, ticaret alanları, teknoloji parklarl, kamu hizmeti alanlarl, rekreasyon alanlarl ve her türlü sosyal donatı alanları oluşturmak, eskiyen kent klsımların yeniden inşa ve restore etmek, kentin tarihi ve kültürel dokusunu korumak veya deprem riskine karşı tedbirler almak amacıyla kentsel dönüşüm ve gelişim projeleri uygulayabilir. Bir alanın kentsel dönüşüm ve gelişim alanı olarak ilan edilebilmesi için yukarıda sayılan hususlardan birinin veya birkaçının gerçekleşmesi ve bu alanın belediye veya mücavir alan sinırları içerisinde bulunması şarttır." 
“Büyükşehir belediye ve mücavir alan sinırları içinde kentsel dönüşüm ve gelişim projesi ilan etmeye büyükşehir belediyeleri yetkilidir. Büyükşehir belediyesi meclisince uygun görülmesi halinde ilçe belediyeleri kendi sınırları içinde kentsel dönüşüm ve gelişim projeleri uygulayabilir. Büyükşehir belediyeleri tarafindan yapılacak kentsel dönüşüm ve gelişim projelerine ilişkin her ölçekteki imar plant, parselasyon planı, bina inşaat ruhsatı, yapı kullanma izni ve benzeri tüm imar işlemleri ve 3/5/1985 tarihli ve 3194 sayılı İmar Kanununda belediyelere verilen yetkileri kullanmaya büyükşehir belediyeleri yetkilidir."

Kuşkusuz 5998 sayılı Kanunla getirilen değişikliğe ilişkin en fazla eleştiri, büyükşehir belediyelerine geniş yetkiler verilmesine yönelik yapılmıştır. Görüldüğü üzere büyükşehir belediyelerine "kentsel dönüşüm ve gelişim proje alanı" belirleme yetkisinin yanı sıra bu alanlarda plan ve parselasyon yapma, bina inşaat ruhsatı ve yapı kullanma izni verme gibi çok geniş yetkiler verilmiştir. $\mathrm{Bu}$ durumun, ilçe belediyelerini yetkisizleştirdiğine yönelik eleştiriler söz konusudur (TUPOB, 2010).

İlçe belediyelerinin kendi sınırları içinde kentsel dönüşüm projesi uygulayabilmesi, büyükşehir belediye meclisinin uygun görmesine bırakılmıştır. Yani büyükşehir belediyelerinin hiçbir sınırlama, denetim ve izine tabi olmaksızın kentsel dönüşüm ve gelişim alanı belirleyebilmesi ile ilçe belediyelerinin büyükşehir belediyelerinin vesayeti altına sokulduğu düşünülmektedir (Mimarlar Odas1, 2010).

Ayrıca söz konusu düzenlemede 3194 sayılı İmar Kanunu ile ilçe belediyelerine verilen yetkilerin büyükşehir belediyelerine devredildiği görülmektedir. Bu yetki ile büyükşehir belediyeleri, kendileri ile aynı siyasi görüşü paylaşmayan ilçe belediyelerinde, ilçe belediyelerinin böyle bir tercihi olmasa dahi, kentsel dönüşüm ve gelişim alanı ilan edebilecektir. Bu durum aynı zamanda kent içerisinde veya çeperinde yer alan rant değeri yüksek alanlarda hâlihazırda yaşayan dar gelirlilerin yerlerinden edilerek bunların yerine lüks konutların ya da alışveriş merkezlerinin yapılmasını kolaylaştırabilecektir (Mimarlar Odası, 2010).

\section{AFET RİSKİ ALTINDAKİ ALANLARIN DÖNÜŞTÜRÜLMESİ HAKKINDA}

\section{KANUN}

1982 Anayasasına göre devletin önemli görevlerinden biri, şehirlerin özelliklerini ve çevre şartlarını gözeten bir planlama çerçevesinde konut ihtiyacını karşılamaktır. Ancak afet riski, anayasal bir hak olan sağlıklı ve dengeli bir çevrede yaşama hakkının kullanılmasını zorlaştırmaktadır. $\mathrm{Bu}$ durumda devlet, afet riskini en aza indirecek tedbirler almakla yükümlüdür (Özer vd., 2013: 473). 31 
Mayıs 2012 tarihinde yürürlüğe giren 6306 sayılı Kanun, Türkiye'deki deprem gerçeği karşısında ve devletin bu yükümlülüğünün bir sonucu olarak atılan önemli bir adım niteliğindedir.

Nitekim 6306 sayılı Kanunun gerekçe metninde; "Ülkemizde başta deprem olmak üzere afet riskinin yüksek olmasına karşın yapı stokumuzun büyük bir kısmının güvensiz ve imar mevzuatına aykırı olması, kaçak yapılaşmanın çok fazla olması nedenleriyle afetler oluşmadan önce gerekli tedbirlerin alınmasına yönelik bir mevzuata acil olarak ihtiyaç duyulmaktadır." ifadelerine yer verilmiştir (IMO, 2012: 11).

“Kentsel Dönüşüm Kanunu” olarak bilinen 6306 sayılı Kanun, afet riski altındaki alanlar ile bu alanlar dışındaki riskli yapıların bulunduğu arsa ve arazilerde sağlıklı ve güvenli yaşama çevreleri oluşturmak için iyileştirme, tasfiye ve yenilemelere dair usul ve esasları düzenlemektedir (md. 1). Kanunun ardından 04 Ağustos 2012 tarihinde yayımlanan Uygulama Yönetmeliği’nin tamamı, 15 Aralık 2012 tarihinde yayımlanan yeni Uygulama Yönetmeliği ile değiştirilmiştir. Çalışmada önce 6306 sayılı Kanun ve getirdiği değişiklikler, ardından kanunun uygulanmasına yönelik eleştirilere yer verilecektir.

\subsection{Sayılı Kanun ve Getirdiği Değişiklikler}

6306 sayılı Kanun, uygulama alanı olarak afet riski altındaki yerleri ve afet riski olmayan yerlerde de riskli yapıları tespit etmiştir. Kanunun 2. maddesindeki riskli yapı tanımından yola çıkılarak üç çeşit riskli yapının olduğu anlaşılmaktadır: ekonomik ömrünü tamamlamış olan yapı, ağır hasar görme riski ilmi ve teknik verilere dayanılarak tespit edilen yapı, yıkılma riski taşıdığı ilmi ve teknik verilere dayanılarak tespit edilen yapı. Ayrıca kanuna göre "uygulama bütünlügüu” adı altında riskli yapılar dışında kalan yapılardan Bakanlıkça gerekli görülenler de bu kanun hükümlerine tabi olacaktır (md.3).

6306 sayılı Kanunun uygulanmasında bakanlık, Çevre ve Şehircilik Bakanlığını; idare ise belediye ve mücavir alan sınırları içinde belediyeleri, bu sınırlar dışında il özel idarelerini, büyükşehirlerde büyükşehir belediyelerini ve Bakanlık tarafından yetkilendirilmesi halinde büyükşehir belediyesi sınırları içindeki ilçe belediyelerini refere etmektedir (md.2). Riskli alan ve rezerv yapı alanı ile riskli yapıların bulunduğu taşınmazlara ilişkin her tür ve ölçekteki planı yapma, yaptırma ve onaylama yetkisi Çevre ve Şehircilik Bakanlığı'na verilmiştir (md.6).

Riskli yapıların tespiti; malikler tarafından, masrafları kendilerine ait olmak üzere, Bakanlıkça lisanslandırılan kurum ve kuruluşlar tarafından yaptırılmaktadır. Bakanlık, riskli yapıların tespitini süre vererek maliklerden, kanuni temsilcilerinden veya idareden de isteyebilir. Riskli yapı tespitlerine karşı maliklerin 15 gün içinde itiraz etme hakkı bulunmaktadır. Bu itirazlar; dördü ilgili meslek 
disiplini öğretim üyesi, üçü ise Bakanlık temsilcisi olmak üzere yedi kişiden oluşan teknik heyetler tarafindan incelenerek karara bağlanmaktadır (md.3).

Riskli yapı tespitine ilişkin raporların bir örneği, tespit tarihinden itibaren en geç 2 gün içinde Çevre ve Şehircilik İl Müdürlüğü’ne gönderilir ve ilgili tapu müdürlüğüne bildirilir (www.kocaeli.bel.tr). Böylece yapının kiralanması veya satılmasında riskli olduğunun bilinmesi sağlanmaktadır (Aydın, 2013: 52).

6306 sayılı Kanun çerçevesinde riskli olduğu tespit edilen alanlardaki yapıların yıktırılması gereği ortaya çıkmaktadır. Yapıların yıktırılmasında malikler ile idarenin anlaşması teşvik edilmektedir. Anlaşma sağlanan hak sahiplerine geçici konut, işyeri tahsisi ve kira yardımı yapılabileceği belirtilmiştir. Riskli yapıların yıktırılması için maliklere verilen 60 günlük süre içinde yapının yıktırılmaması halinde yapının idari makamlarca yıktırılacağı belirtilip ek bir süre daha verilmektedir. Bu süre içinde yapı yine yıktırılmamış ise mahalli idarelerin iştiraki ile mülki amirler tarafindan yıktırılmaktadır (md.5).

Üzerindeki bina yıkılarak arsa haline gelen taşınmazlarda yapılacak uygulamalarda 2/3 çoğunluğun kararı esas alınmaktadır. Bu çoğunluğa katılmayanların payları, anlaşma sağlayan diğer paydaşlara açık arttırma usulü ile satılmaktadır. Bu şekilde satılamayan paylar, tapuda Hazine adına resen tescil edilmekte ve Bakanlıkça uygun görülenler TOKİ'ye veya İdareye devredilmektedir. 2/3 çoğunluk ile anlaşma sağlanamadığı durumda ise; Bakanlık, TOKİ veya İdare tarafından acele kamulaştırma yoluna gidilebilecektir (md.6).

$\mathrm{Bu}$ konuya ilişkin getirilen yeni bir düzenleme, 25 Temmuz 2014 tarihinde Uygulama Yönetmeliği’nde yapılan bir değişiklik ile riskli alan dışında kalan riskli yapılar için kat maliklerine güçlendirme kararı alabilme imkanının getirilmiş olmasıdır. Böylece yıkıma karşı çıkan kat malikleri, güçlendirmenin teknik olarak mümkün olduğunu tespit edip bir proje sunarak güçlendirme yönünde karar alınmasını sağlayabilecektir. Güçlendirme kararının ne şekilde alınacağı konusunda Kat Mülkiyeti Kanunu'nun 19/2 fikrasına gönderme yapılmıştır. Buna göre kat maliklerinin 4/5'inin yazılı rizası gerekmektedir (Sevinç, 2014).

6306 sayılı Kanun uyarınca tesis edilen idari işlemlere karşı otuz gün içinde İdari Yargılama Usulü Kanunu'nca dava açılabilecek; ancak bu davalarda yürütmenin durdurulmasına karar verilemeyecektir (md.6). İdarenin denetim yollarından olan yargısal denetimin açıkça devre dışı bırakıldığını gösteren bu madde, Anayasa Mahkemesi tarafindan 2012/87 Esas Sayılı ve 2014/41 Karar Sayılı Karar ile 27 Şubat 2014 tarihinde iptal edilmiştir.

6306 sayılı Kanunun "Uygulanmayacak Mevzuat" başlıklı 9. maddesinde, kanunun uygulanmasını engelleyici ve bu kanuna aykırı olan hükümleri uygulanmayacak olan diğer kanunlar 
sayılmaktadır. Bunlar arasında; Orman Kanunu, Kıyı Kanunu, Mera Kanunu, Kültür ve Tabiat Varlıklarını Koruma Kanunu gibi kanunlar yer almaktadır.

Son olarak, 6306 sayılı Kanuna ilişkin iş ve işlemleri engelleyenler hakkında, Türk Ceza Kanunu'nun ilgili hükümleri uyarınca Cumhuriyet Başsavcılığına suç duyurusunda bulunulacağı, 8 . maddede öngörülmüştür. Bu kişi bir kamu görevlisi ise, tabi olduğu ceza ve disiplin hükümleri uygulanacaktır.

6306 sayı1ı Kanunun uygulanmasına ilişkin belli başlı maddeler bu şekildedir. Geçmiş depremler düşünüldüğünde gelecekteki potansiyel depremler sebebiyle riskli alanların ve yapıların acilen dönüştürülmesi hususunda bir tereddüt yoktur. Çünkü aksi durumda ortaya çıkacak can ve mal kaybından idare sorumlu olacaktır (Çolak, 2013: 19, 23). Bu kapsamda 6306 sayılı Kanun, doğal afet risklerinin azaltılması çerçevesinde bütüncül mevzuat eksikliğinin giderilmesine yönelik atılan önemli bir adımdır (Genç, 2014: 29).

Ancak bu durum, kanunun eleştirilmesine engel olmamıştır. Kanunun geneli itibariyle uygulamada belli başlı sorunlara yol açacağı düşünülmektedir (Aydınlı ve Kaya, 2013: 462). Bu doğrultuda afet riski açısından sorunlu alanların dönüştürülmesi uygulamalarının olumlu yönlerini gölgede bırakacak bazı eleştiriler gündeme gelmektedir (Çolak, 2013: 30).

\subsection{Sayılı Kanunun Uygulanmasına Yönelik Eleştiriler}

6306 sayılı Kanunun uygulanmasına yönelik eleştirilerin temel odak noktası, büyük ölçüde Çevre ve Şehircilik Bakanlığı'nı, yani merkezi yönetimi yetkilendirmesidir. Böylece Bakanlık, uygun gördüğü herhangi bir alanı riskli alan ilan edebilecek ve bu alanlardaki her türlü uygulamayı kendi başına yürütebilecektir (Dükkanc1, 2013: 93-99).

Bir kamu tüzelkişisinin bu denli büyük yetkilerle donatılarak kanunun hazırlayıcısı, uygulayıcısı ve denetleyici olması büyük ölçüde eleştirilmekle birlikte karşı görüş konunun yıllardır çözülememesini finansman ve yetki karmaşasına bağlayarak Bakanlığın ön plana çıkarılmasının gerekli olduğunu savunmaktadır (Sönmezocak, 2013: 5).

Ayrıca uygulama bütünlüğü açısından risk taşımayan yapılar arasında Bakanlıkça gerekli görülenler de bu kanun hükümlerine tabi olabilecektir. Bu durum, Bakanlığa verilen geniş yetkilerden biri olup hukuki güvencelerin ve mülkiyet hakkının ihlal edilmesi anlamına gelmektedir. Bu ibare ile getirilen muğlaklık, özel mülkiyete konu olan taşınmazlar açısından güvensizlik yaratmakta ve kişi özgürlüklerinin sınırlarını belirsiz bir hatta çekmektedir (Sönmezocak, 2013: 4). 
6306 sayılı Kanunun karakteristiğini belirleyen riskli alan tespitinde Bakanlıkça lisanslandırılan kurum ve kuruluşların yetkili olması ve riskli yapı tespitine ilişkin yapılan itirazların incelenmesinde görevli olan teknik heyette Bakanlık temsilcilerinin yer alması, dönüşüm sürecinde Bakanlığın taraf olması sebebiyle objektifliğe zarar verebilecektir (Özer vd., 2013: 474).

Riskli yapıların yıktırılmasında idare ile anlaşan hak sahiplerine geçici konut, işyeri tahsisi ve kira yardımı "yapılabileceği” belirtilmiştir. Bu ifade, idareye geçici konut ve işyeri tahsis edip etmeme hususunda bir takdir yetkisi tanındığını göstermektedir. Esasen burada idare açısından olması gereken takdir yetkisi değil, bağlı yetkidir (Sönmezocak, 2013: 4-5). Ayrıca idareye tanınan takdir yetkisi dışında söz konusu yardımların hangi kanallarla yapılacağı ve kimlerin bu yardımlardan faydalanacağı gibi konulara ilişkin kanunda bir netlik bulunmamaktadır.

Üçte iki çoğunluk ile anlaşma sağlanamadığı durumlarda ise Bakanlık, TOKİ veya İdarenin acele kamulaştırmaya başvurabileceği belirtilmiştir. Kamulaştırmanın anlamı, konut veya işyerinin devlete geçmesi, devletin belirleyeceği bedelin $1 / 5$ 'ini peşin ödemesi ve kalan kısmın ödemesini de 5 yıl içinde tamamlamasıdır (Öngören ve Çolak, 2013: 156). Ayrıca acele kamulaştırma hak sahiplerini mağdur edebilecek bir nitelikte olup, buradaki acelecilik gerekçesinin somut bir şekilde belirtilmesini gerektirmektedir.

Çevre ve Şehircilik Bakanlığı riskli binaları kamulaştırırken arsanın değerini arsa üzerinde bulunan eski gayrimenkul özelliklerine göre belirleyebilmektedir. Ancak yeniden imar edilecek bir arsanın değerinin eski gayrimenkullerin değil, yeni gayrimenkullerin özelliklere göre belirlenmesi gerekir. Kanunun kentsel dönüşüm projeleri bağlamında ortaya çıkacak arsa değerleri üzerinde bir değerleme sürecini dikkate almaması hak sahipleri açısından kentsel dönüşüm sürecini zorlaştıracaktır (Baydur, 2013: 16).

Ayrıca 6306 sayılı Kanunla normlar hiyerarşisi anlamında birbiriyle eşit nitelikte olan diğer kanunlar yok sayılmıştır. Böylece kentsel dönüşüm amacıyla bu kanunlar tarafından korunan ormanlar, meralar gibi alanlar uygulama kapsamına alınarak yapılaşmaya açılabilecektir (Öngören ve Çolak, 2013: 270; Özer vd., 2013: 474).

Bu noktada yeni bir uygulama olan “Anahtar Teslim Kentsel Dönüşüm Projesi” değinmek gerekmektedir. Çevre ve Şehircilik Bakanlığının desteği çerçevesinde Garanti Mortgage'in, Kentsel Dönüşüm ve Hukuk Platformu ile birlikte geliştirdiği "Anahtar Teslimi Kentsel Dönüşüm Projesi”nde inşaat şirketlerinin imar artışı veya kendilerine düşecek ilave kat olmadığı için yapımını üstlenmeyi tercih etmedikleri binaların kentsel dönüşümünde, maliklerin binalarını yaptırmaları için gereken finansman ve koordinasyonun, Garanti Mortgage önderliğinde proje ortaklarıyla yürütülmesi sağlanacaktır. İstanbul olarak pilot 
bölgenin seçildiği “Anahtar Teslim Kentsel Dönüşüm Projesi”nde Garanti Mortgage, değerleme ve yapı denetim şirketleri ile inşaat yapım süreçlerini denetleyecek, binayı yeniden yapacak inşaat şirketi de inşaat yapım bedeline karşılık gelen hak edişlerini Garanti Mortgage'den alacaktır. Evlerini yenilemek isteyen hak sahipleri başlatılan kentsel dönüşüm süreci sonunda yeni dairelerini anahtar teslim alabilecektir. Ayrıca üyeler kat karşıllı̆̆ inşaat yapımı yanında "para karşılığı inşaat yapma” sürecine de yönlendirilecektir. Proje sayesinde, inşaat yapım bedeli daha baştan Garanti Mortgage'de hazır olacağından inşaat şirketleri ve daire sahipleri açısından güvenilir ve endişesiz bir sistem oluşturulması planlanmaktadır (http://www.kentseldonusumvehukuk.com).

Sonuç olarak görülmektedir ki; 6306 sayılı Kanun yalnızca merkezi yönetime geniş yetkiler vermekle kalmamış; aynı zamanda kanunun uygulanmasına ilişkin denetleme, hesap verebilirlik ve şeffaflık gibi kavramları da ortadan kaldırmıştır (Dükkanc1, 2013: 119). Nusret İlker Çolak’a (2013: 34) göre, kamu gücü kullanılarak, dönüştürülen alanda yerleşik kişilerin başta mülkiyet hakkı olmak üzere kimi hak ve özgürlüklerinin kullanılmaz duruma getirilerek gerçekleştirilecek bir değişimin adı “dönüşüm” olmamalıdır. Bu durumda "kenti dönüştürme" ifadesi daha uygun olacaktır.

6306 sayılı Kanuna göre dönüşüm sadece ekonomik ve fiziksel boyutları ile ele alınmakta, ortaya çıkaracağı sosyal sorunlar göz ardı edilmektedir. Eleştirilerin yoğunlaştığı bir diğer nokta, kentsel dönüşüm projelerini meşrulaştırmak için deprem riskinin bir bahane olarak kullanılacağına ilişkindir (Genç, 2014: 26). Benzer şekilde İnşaat Mühendisleri Odası da bu kanunun sağlıklı bir kentsel yenilemeyi sağlayamayacağı gibi başta metropol kentler olmak üzere tüm ülkeyi bir rant alanı haline dönüştüreceğini savunmaktadır (İMO, 2012: 15).

İlhan Tekeli (2014), kentsel dönüşüm projelerinin bir kısmının kentlerdeki yapısal sorunlar nedeniyle ortaya çıkmasına karşılık diğer bir kısmın "Psödö Projeleri” olduğunu belirtmektedir. Bu projelerin en önemli özelliği olarak siyasal tercihlerden kaynaklanmalarını göstermektedir. Gecekondu alanlarının dönüş̧ürülmesi, yerel ve merkezi idareler tarafindan değersiz görülen alanların dönüştürülmesi ve deprem riskinden kaynaklanan dönüştürme projelerini bu gruba dahil etmektedir.

Tekeli’ye (2014) göre bu gruptaki dönüşüm projelerinin meşruiyetini temellendirirken çok dikkatli olmak gerekir. Örneğin, bir belediye başkanı seçimle işbaşına gelmesine rağmen bu ona tek başına bir dönüşüm projesine karar vermek için meşruiyet sağlamaz. Ayrıca dönüşüm projelerinin yalnızca bir plana dayandırılması da yeterli olmayacaktır. Burada yapılması gereken şeffaf, hesap verebilir ve katılımcı pratiklerin hayata geçirilmesidir. Bunlar yapılmadan gerçekleştirilen kentsel dönüşüm projeleri Tekeli’ye (2014) göre “o kentte burunlara temiz olmayan kötü kokular” gelmesine neden olacaktır. 


\section{SONUÇ}

Türkiye'de kentsel dönüşüm 1950li yıllarda kırdan kente göç süreçleriyle birlikte konut stokunun niteliksiz hale gelmesi sonucunda bir gereksinim olarak ortaya çıkmıştır. Niteliksiz konut stoku kadar doğal afet riskinin yüksekliği de Türkiye açısından kentsel dönüşümü bir zorunluluk haline getirmiştir. 1999 Marmara Depremi sonrasında çok sayıda yasal düzenleme yapılmışsa da afet oluşmadan önce tedbir alınması gerekliliği ve 2011 Van Depreminde yaşanan yüksek can ve mal kayıpları yeni bir yasal düzenleme yapılması ihtiyacını ortaya çıkarmıştır.

$\mathrm{Bu}$ doğrultuda çıkarılan 6306 sayılı Kanun önemli bir kanun olmakla birlikte kanunun uygulanmasına ilişkin maddeler, çeşitli sivil toplum kuruluşları ve bilim insanları tarafından eleştirilere maruz kalmıştır. Bu eleştirileri gruplandırarak özetlemek gerekirse;

Merkezi yönetimin artan rolü: Kanunda yetkili idareler arasında yerel yönetimler say1lmakla birlikte yerel yönetimler açısından bu yetkilerin kullanılması Çevre ve Şehircilik Bakanlığı'nın yetki devrine bırakılmıştır. Kanunda yer alan ve Bakanlığa geniş yetkiler veren maddelere örnek vermek gerekirse;

- Riskli yapı tespitinin Bakanlıkça lisanslandırılan kurum ve kuruluşlara yaptırılacak olması,

- Riskli yapı tespitine karşı yapılacak itirazları inceleyen 7 kişilik heyetin 3'ünün Bakanlık temsilcisi olmas1,

- Riskli alan ve rezerv yapı alanı ile riskli yapıların bulunduğu taşınmazlara ilişkin her tür ve ölçekteki planı yapma yetkisi,

- Uygulama bütünlüğü bakımından riskli yapılar dışında kalan yapılardan Bakanlıkça gerekli görülenlerin de bu kanun hükümlerine tabi olması gibi yetkiler ile Bakanlık bu süreçte giderek artan bir rol üstlenmektedir.

Oysaki yerel yönetimler yerel demokrasinin işleyişi açısından önemli kurumlardır. Coğrafi yakınlık açısından kendi yerelinde var olan sorunları ve bu sorunlara ilişkin çözümleri daha yakından takip etme şansına sahiptir. Ayrıca seçilmiş oldukları da düşünüldüğünde siyasal sorumluluk çerçevesinde yerel halka karşı daha sorumlu davranmaları beklenir.

Bunların yanı sıra bu durum, anayasanın 127. maddesinde yer alan "yerinden yönetim" ilkesi ve Türkiye'nin de taraf olduğu Avrupa Yerel Yönetimler Özerklik Şartı gibi düzenlemeler açısından merkezi yönetim-yerel yönetim arasındaki dengenin yerel yönetim aleyhine bozulmasına neden olacaktır. Bilindiği üzere Avrupa Yerel Yönetimler Özerklik Şartı'nın 4. maddesi, "kamu sorumluluklarının genellikle ve tercihen vatandaşa en yakın makamlar tarafından kullanılacağını" hükme bağlamaktadır. 
Mülkiyet hakkının ihlali: Mülkiyet hakkı bilindiği üzere çeşitli ulusal ve uluslararası düzenlemeler ile koruma altına alınmıştır. Ancak kanundaki bazı düzenlemeler, buna aykırı bir biçimde mülkiyet hakkının sahibine verdiği tasarrufta bulunma yetkisini sınırlandırmaktadır. $\mathrm{Bu}$ düzenlemelere örnek vermek gerekirse;

- Üzerindeki bina yıkılarak arsa haline gelen taşınmazlarda yapılacak uygulamalarda 2/3'lik çoğunluğa katılmayan azınlığın payları açık arttırma ile $2 / 3$ çoğunluğa satılacak, satılmaması durumunda da Hazine adına resen tescil edilecektir. Anlaşma sağlanamaması durumunda ise acele kamulaştırma yoluna gidilebilecektir.

- Uygulama bütünlüğü adı altında riskli yapılar dışında kalan yapılardan Bakanlıkça gerekli görülenler de bu kanun hükümlerine tabi olacaktır.

- Kanun kapsamındaki proje ve uygulamalar süresince her türlü imar ve yapılaşma işlemleri geçici olarak durdurulabilecektir. Nitekim bu madde, Anayasa Mahkemesi tarafindan iptal edilmiştir (27.02.2014,2012/87 E,2014/41 say1lı karar).

Merkezi yönetimin artan rolü ve mülkiyet hakkının ihlaline ilişkin eleştiriler temelde TOKİ aracılığıyla merkezi yönetimin projeler sonrasında elde edilecek ranta el koyma isteği noktasında buluşturulabilir. Kentsel dönüşüm, kentsel rantın en hızlı ve en kolay sağlandığı uygulama alanlarından biridir. Bu kanunla birlikte merkezi yönetim kendisini kentsel dönüşüm projelerinde hem hazırlayıcı, hem uygulayıcı hem de denetleyici ilan etmiştir. Bu doğrultuda her iki gruptaki eleştiri de “merkezi yönetime rant transferi” söylemleri çerçevesinde birleştirilebilir.

Uygulanmayacak Mevzuat: Orman Kanunu, Kıуı Kanunu, Mera Kanunu, Kültür ve Tabiat Varlıklarını Koruma Kanunu gibi birçok kanun, 6306 sayılı Kanunla yok sayılmaktadır. Ülkemiz açısından önemli doğal ve kültürel kaynaklar olan ormanlar, meralar ve kıyı alanlarının yapılaşmaya açılabilecek olması rant endişelerini gündeme getirmektedir. Ayrıca bu kanunlar, normlar hiyerarşisi bakımından 6306 sayılı Kanunla eşit durumda iken kanuna koşulsuz üstünlük tanınması yine kanunun çıkarılış gerekçesinin sorgulanmasına yol açmaktadır.

Görüldüğ̈̈ üzere 6306 sayılı Kanunun çıkarılış gerekçesi ile uygulamaya yönelik maddeleri çelişmekte, maddelerin büyük bir çoğunluğu mülkiyet hakkına ve hukuk devleti ilkelerine aykırılık teşkil etmektedir. Yaşama hakkı, mülkiyet hakkından önemli kabul edilebilir. Ancak yaşama hakkı, yalnızca fiziksel olarak varlığını sürdürmek anlamına gelmez. İnsanların afet ya da deprem riski kullanılarak yerlerinden edilmesi ve kent dışına yerleştirilmesi, insan onuruna yaraşır bir şekilde yaşamak haklarının ellerinden alınması anlamına gelecektir.

Dönüşümün fiziksel ve ekonomik boyutu olduğu kadar sosyal boyutu olduğu da unutulmamalıdır. Çünkü insan mekanı, mekan da insanı şekillendirmektedir. Hak sahiplerinin rızası 
alınmadan bu denli kapsamlı dönüşüm uygulamaları yapmak, endişeleri ve kaygıları haklı çıkaracak ve inandırıcıllı̆ı zedeleyecektir. Bunu engellemek için öncelikle Bakanlığa tanınan yetkiler sınırlandırılarak bir denetim mekanizması işler hale getirilmelidir. Sürece ilişkin vatandaşın bilgilendirilmesi, meslek odaları, sivil toplum kuruluşları ve üniversitelerin katılımının sağlanması, şeffaf ve hesap verebilir bir yönetimin oluşturulması, sosyolojik ve çevresel değişkenlerin hesaba katılması gibi konular hayati bir önem arz etmektedir.

Afet riski, soylulaştırma ve dar gelirli grupların yerinden edilmesi için bir bahane olmamalı ve rant amaçlı projeler için bir araç olarak kullanılmamalıdır. Toplumun dar gelirli kesimlerinin yaşadıkları mahallelerin yıkılması için afet riski bir meşruluk yaratmamalıdır. Aksi takdirde kanunun bizzat kendisinin toplumsal afetler yaratması kaçınılmaz olacaktır.

\section{KAYNAKÇA}

AFAD (2014) "Müdahale, İyileştirme ve Sosyoekonomik Açıdan 2011 Van Depremi", http://sitap.org/mudahale-iyilestirme-ve-sosyoekonomik-acidan-2011-van-depremi/, $(12.05 .2015)$

Akkar, M. (2006) “Kentsel Dönüşüm Üzerine Batı’daki Kavramlar, Tanımlar, Süreçler ve Türkiye”, Planlama Dergisi, $\quad$ http://www.spo.org.tr/resimler/ekler/2aee86157b4a40b ek.pdf, $(01.05 .2015)$

Ataöv, A. ve Osmay, S. (2007) “Türkiye'de Kentsel Dönüşüme Yöntemsel Bir Yaklaşım”, METU JFA, 24 (2): 57-82.

Aydın, F. (2013) “Afet Riski Altındaki Alanların Dönüştürülmesi "6306 Sayılı Yasa” İstanbulEsenler Örneği”, Yüksek Lisans Tezi, Bahçeşehir Üniversitesi, Fen Bilimleri Enstitüsü, İstanbul.

Aydınlı, H. İ. ve Kaya, A. (2013) "Yarg1 Kararları Örnekleri ile Türkiye’de Kentsel Dönüşüm Uygulamalarının Sorun Alanları”, Afyon Kocatepe Üniversitesi İ̈BF Dergisi, 15 (2): 449-469.

Aydınlı, H. İ. ve Turan, H. (2012) "Kuramsal ve Yasal Çerçevede Türkiye'de Kentsel Dönüşüm”, Selçuk Üniversitesi Sosyal Bilimler Enstitüsü Dergisi, 28: 61-70.

Ayhan, F. (2013) "Kentsel Dönüşüm Kavramı ve Tarihsel Gelişimi”, (ed.) M. Yasin ve C. Şahin, Kentsel Dönüşüm Hukuku, İstanbul Üniversitesi S.S.ONAR İdare Hukuku ve İlimleri Araştırma ve Uygulama Merkezi Yayınları, 2013/1: 71-90.

Baydur, C. M. (2013) “Kentsel Dönüşüm Kanunu ve Yeniden İmar Süreci Üzerine Düşünceler”, Finans, Politik ve Ekonomik Yorumlar Dergisi, 575: 7-17. 
Bayındırlık ve İskan Bakanlığı'nın Marmara ve Düzce Depremleri Sonrası Faaliyetleri Hakkında Performans Denetim Raporu. http://www.sayistay.gov.tr/yayin/dergi/icerik/der44-45m5.pdf, (12.05.2015)

Boyraz, Z. ve Hoş, B. Y. (2014) “Türkiye'de Kentsel Dönüşüm Uygulamaları”, Journal of World of Turks, 6 (3): 45-63.

Çolak, N. İ. (2013) "Kentsel Dönüşüm Mevzuatının Hukuksal Değerlendirmesi”, http://www.yargitay.gov.tr/abproje/belge/conf8/kentselDonusumMevzHukuksalDegerlendirm eN.Colak.pdf, (13.02.2015)

Demirkol, S. ve Baş, Z. B. (2013) "Kentsel Dönüşümün 6306 Sayılı Yasa Kapsamında Hak ve Özgürlükler Açısından Ele Alınması”, TBB Dergisi, 108: 23-70.

Dükkanc1, U. (2013) “Türkiye'de Kentsel Dönüşüm Sürecinin Gelişimi ve Günümüzdeki YasalYönetsel Boyutunun İrdelenmesi”, Yüksek Lisans Tezi, Yıldız Teknik Üniversitesi, Fen Bilimleri Enstitüsü, İstanbul.

Ergun, C. ve Gül, H. (2010) “Barınma Hakkının İhlal Edilme Sürecinde Kentsel Dönüşüm Projeleri”, Sosyal Haklar Ulusal Sempozyumu, http://www.sosyalhaklar.net/2010/bildiri/ergun.pdf, (03.02.2015)

Genç, F. N. (2014) “Gecekonduyla Mücadeleden Kentsel Dönüşüme Türkiye'de Kentleşme Politikaları”, Adnan Menderes Üniversitesi Sosyal Bilimler Enstitüsü Dergisi, 1 (1): 15-30.

Göksu, F. (1993) “Portakal Çiçeği Vadisi Kentsel Gelişme Projesi”, Ankara Dergisi, 2 (5): 83.

Görün, M. ve Kara, M. (2010) "Kentsel Dönüşüm ve Sosyal Girişimcilik Bağlamında Türkiye'de Kentsel Yaşam Kalitesinin Artırılması", Çanakkale Onsekiz Mart Üniversitesi Yönetim Bilimleri Dergisi, 8 (2): 139-164.

İMO, (2012) "Deprem Bahanesi ve Kentsel Dönüşüm Projeleri”, TMH-471-2012/1, http://www.imo.org.tr/resimler/dosya_ekler/75eeed55b207636_ek.pdf?dergi=260, $(01.02 .2015)$

Jones, P., Evans, J. (2008) "Urban Regeneration In The UK", First Published, London, Sage Publications.

Keleş, R. (2008) “Kentleşme Politikası”, Ankara: İmge Yayınevi.

Kocaer Şenyol, Ö. ve Bal, Ö. H. (2013) "Kentsel Dönüşüm Gerçeği ve İzmir Uygulamaları Üzerine Bir Değerlendirme", TMMOB 2. İzmir Kent Sempozyumu, 445-452. 
Köktürk, E. ve Köktürk, E. (2007) “Türkiye'de Kentsel Dönüşüm ve Almanya Deneyimi”, TMMOB Harita ve Kadastro Mühendisleri Odas1 11. Türkiye Harita Bilimsel ve Teknik Kurultayı, Ankara, 1-18.

Öcal, C. ve İnce, H. H. (2012) “Türkiye'de Mevcut Yap1 Stoğu ve Kentsel Dönüşüm”, SDU International Technologic Science, 4 (2): 89-95.

Öngören, G. ve Çolak, N. İ. (2013) “Kentsel Dönüşüm Hukuku Kentsel Dönüşüm Rehberi”, İstanbul: Tor Ofset.

Özden, P. P. (2006) “Türkiye’de Kentsel Dönüşümün Uygulanabilirliği Üzerine Düşünceler”, İstanbul Üniversitesi Siyasal Bilgiler Fakültesi Dergisi, 35: 215-233.

Özer, Y. E., Yönten, A. ve Yılmaz, F. (2013) “Afet Riski Taşıyan Bölgelerdeki Kentsel Dönüşüm Uygulamalarında Sosyo Beşeri Faktörlerin İncelenmesi Üzerine Bir Çalışma: Uzundere Toki Dayanışma ve Yardımlaşma Derneği Örneği”, 8. Kamu Yönetimi Sempozyumu, Hatay, http://kisi.deu.edu.tr/yunusemre.ozer/KENTSEL\%20DONUSUM.pdf, (11.05.2015)

Özer, Y. E., Yönten, A. ve Yılmaz, F. (2013) “Afet Riski Taşıyan Bölgelerde Kentsel Dönüşüm Uygulamaları ve Kadifekale'deki Kentsel Dönüşümün Sosyal Boyutu”, Yakup Bulut, Veysel Eren, Sedat Karakaya, Abdullah Aydın (Ed.), Kuramdan Uygulamaya Yerel Yönetimler ve Kentsel Politikalar içinde (s. 468-479). Ankara: Pegem Yayınevi.

Polat, S., Dostoğlu, N. (2007) “Kentsel Dönüşüm Kavramı Üzerine: Bursa'da Kükürtlü ve Mudanya Örnekleri”, Uludağ Üniversitesi Mühendislik-Mimarlık Fakültesi Dergisi, 12 (1): 61-76.

Saraç, M. (2014) “Kentsel Dönüşüm ve Gelişimi, Sosyal Boyutu, Kentsel Dönüşümden Doğan Hukuki Sorunlar”, Yüksek Lisans Tezi, Çankaya Üniversitesi, Sosyal Bilimler Enstitüsü, Ankara.

Sevinç, S. (2014) “6306 Sayılı Kanuna Göre Riskli Yapıların Güçlendirilmesi”, http://www.erdemerdem.com/articles/6306-sayili-kanuna-gore-riskli-yapilarin-guclendirilmesi/, (10.02.2015)

Sey, Y. (1998) “Cumhuriyet Döneminde Konut”, 75 Yılda Değişen Kent ve Mimarlık, (ed.) Y. Sey, Tarih Vakf1 Yayınları, 273-300.

Sönmez Özbek, İ., Sönmez, A. (2012) “Konut Çevrelerinin Üretiminde Dönüşüm ve Farkl1 Yaklaşımların Etkileri”, TMMOB Mimarlar Odası 24. Uluslararası Yapı Yaşam Kongresi, Bursa.

Sönmez, F., Geniş, Ş. (2013) “Türkiye Soylulaştırma Yazınının Eleştirel Bir Değerlendirmesi”, (ed.) M. Tuna, Muğla Sitkı Koçman Üniversitesi VII. Ulusal Sosyoloji Kongresi Yeni Toplumsal Yapılanmlar: Geçişler, Kesişmeler, Sapmalar Bildiri Kitabı I, Muğla, 127-140. 
Sönmezocak, E. B. (2013) "Kentsel Dönüşüm Kavramı ve 6306 Sayılı Kanunun Yol Açabileceği Hukuki Sorunlar", https://www.academia.edu/3334658/Kentsel_D\%C3\%B6n\%C3\%BC\%C5\%9F\%C3\%BCm_K avram\%C4\%B1_ve_6306_say\%C4\%B11\%C4\%B1_Kanunun_Yol_A\%C3\%A7abilece\%C4\% 9Fi_Hukuki_Sorunlar, (08.02.2015)

Şahin, Y. (2013) "Kriz Yönetimi”, Asım Balcı, Ahmet Nohutçu, Namık Kemal Öztürk, Bayram Coşkun (Ed.), Kamu Yönetiminde Çağdaş Yaklaşımlar: Sorunlar, Tartışmalar, Çözüm Önerileri, Modeller, Dünya ve Türkiye Yansımaları içinde (s. 419-448). Ankara: Seçkin Yayınc1lik.

Şişman, A., Kibaroğlu, D. (2009) "Dünyada ve Türkiye'de Kentsel Dönüşüm Uygulamaları", TMMOB Harita ve Kadastro Mühendisleri Odas1 12. Türkiye Harita Bilimsel ve Teknik Kurultay1, Ankara, 1-9.

TDK.(2006).

http://tdk.gov.tr/index.php?option=com_gts\&arama=gts\&guid=TDK.GTS.5548a13cbe66b8.6 $1656375,(11.07 .2015)$

Tekeli, İ. (2014) “Türkiye'de Kent Yöneticileri/Kent Plancıları Kentsel Dönüşüm İçin Bir Ahlaki Çerçeve Oluşturmak Durumundadır”, Kent, Kentli Hakları, Kentleşme ve Kentsel Dönüşüm içinde (s. 303-315). İstanbul: Tarih Vakfi.

TMMOB. (2011) “Türkiye'de Deprem Gerçeği ve TMMOB Makine Mühendisleri Odası’nın Önerileri Oda Raporu", http://www.mmo.org.tr/genel/bizden_detay.php?kod=30181\#.VVHrF47tlHw, (12.05.2015)

Türkiye'de Afetlerin Mekansal ve İstatistiksel Dağılımı Afet Bilgileri Envanteri, Bayındırlık ve İskan Bakanlığ1 Afet İşleri Genel Müdürlüğü, https://www.afad.gov.tr/Dokuman/TR/972014061215307-abep kitap matbaa final 04122008 small.pdf, (12.05.2015)

Türkiye Habitat III Ulusal Raporu. (2014) Çevre ve Şehircilik Bakanlığı, http://www.csb.gov.tr/db/mpgm/editordosya/file/HABITAT/HABITAT\%20III\%20ULUSAL \%20RAPOR_TURKCE.pdf, (20.05.2015)

Türkün, A. (2012) “Kentsel Dönüşüm: Kentsel Ayrışmanın Son Aşaması”, 24. Uluslararası Yap1 Yaşam Kongresi, 279-285.

Ulusal Deprem Stratejisi Kapsamında Mevzuat Geliştirme. www.deprem.gov.tr/sarbis/DDK/DDKIV/DDKIV.../G-Bölümü.doc, (12.05.2015) 
Uzun, C. N. (2006) "Yeni Yasal Düzenlemeler ve Kentsel Dönüşüme Etkileri”, Planlama Dergisi, 2: 49-52.

Yaman, M. (2012) “Türkiye'de Kentsel Dönüş(tür)me Uygulamaları: Sosyo-politik Bir Yaklaşım”, Bursa: MKM Yayıncilık.

Yenice, M. S. (2014) “Türkiye’nin Kentsel Dönüşüm Deneyiminin Tarihsel Analizi”, BAÜ Fen Bil. Enst. Dergisi, 16 (1): 76-88.

Yılmaz, M. (2010) “İmar Kanunu’nun 18. Maddesi Çerçevesinde Düzenleme Ortaklık Payı Kavramı ve Uygulamaları", Marmara Üniversitesi Hukuk Araştırmaları Dergisi, 16 (3-4): 37-83.

3194 Sayılı İmar Kanunu, R.G.:09/05/1985-18749.

4708 Sayılı Yapı Denetimi Hakkında Kanun, R.G.: 13/07/2001-24461.

5104 Sayılı Kuzey Ankara Girişi Kentsel Dönüşüm Projesi Kanunu, R.G: 12.03.2004-25400.

5366 Sayılı Yıpranan Tarihi ve Kültürel Taşınmaz Varlıkların Yenilenerek Korunması ve Yaşatılarak Kullanılması Hakkında Kanun, R.G: 05/07/2005-25866.

5393 Sayılı Belediye Kanunu, R.G:13/07/2005-25874.

5998 Sayılı Belediye Kanununda Değişiklik Yapılmasına İlişkin Kanun, R.G: 24/06/2010-27621.

5998 Sayı11 Kanun Hakkında Mimarlar Odası Antalya Şubesi Raporu (2010), http://ww2.antmimod.org.tr/gundem.asp?blm=2\&serid=152\&procid=0\&page=17, (12.03.2015)

5998 Sayılı Kanuna İlişkin Türkiye Planlama Okulları Birliği (TUPOB) Görüşü (2010), http://www.spo.org.tr/tupob/detay.php?kod=2235\&tipi=56\&sube=0, $(12.03 .2015)$

6305 Sayılı Afet Sigortaları Kanunu, R.G.: 18/05/2012-28296.

6306 Sayılı Afet Riski Altındaki Alanların Dönüştürülmesi Hakkında Kanun, R.G: 31/05/2012-28309.

6306 Sayılı Kanunun Uygulama Yönetmeliği, R.G: 15/12/2012-28498.

http://www.csb.gov.tr/, (17.02.2015)

http://www.kocaeli.bel.tr/Files/Dokumanlar/kentsel_donusum/6306_sayl_kanun_TEMEL_BLGLER_ KTAPCII.pdf, (05.02.2015)

http://www.kentseldonusumvehukuk.com/anahtar-teslim-kentsel-donusum-devri-basladi/, (05.07.2015) 